\title{
Ekonomin som inrättad process
}

\author{
Karl Polanyi
}

SAMMANDRAG: "The economy as instituted process" från 1957 torde vara den näst mest kända texten av Karl Polanyi (I886-1964) efter hans huvudarbete Den stora omdaningen från I944. Här reder han ut skillnaden mellan ekonomibegreppets två innebörder av ekonomi som människors faktiska, substantiella utbyte med naturen och varandra och ekonomi som ett formaliserat tankesystem för rationell optimering. Polanyi argumenterar för att samhällsvetenskapen måste frigöra sig från det ensidiga marknadsperspektiv som följer av den formella innebörden och utgår i stället själv från den förra, substantivistiska, grundbetydelsen när han utvecklar sina begrepp om hur ekonomin egentligen fungerat i olika samhällen genom historien. Ekonomin framstår för Polanyi som en inrättad, eller institutionaliserad, process, mer eller mindre inbäddad i en samhällelig väv av andra institutioner, ekonomiska såväl som icke-ekonomiska. Texten skrevs som ett teoretiskt sammanfattande kapitel till boken Trade and Market in the Early Empires som Polanyi sammanställde tillsammans med Conrad M. Arensberg och Harry W. Pearson. Huvudartikeln introduceras här på svenska dels genom de tre redaktörernas egen prolog till den, dels genom en ny inledning av sociologerna Gunnar Olofsson och Anders Hylmö.

NYCKELORD: ekonomibegreppet; substantivism; formalism; institution; inbäddning; ömsesidighet; omfördelning; utbyte; handel; pengar; marknad.

PUBLICERINGSHISTORIK: Översättning av kapitlen "The economy as instituted process" och "The place of economies in societies" från Karl Polanyi, Conrad M. Arensberg \& Harry W. Pearson (red.), Trade and Market in the Early Empires. Economies in History and Theory, Free Press 1957, och försedd med en nyskriven svensk inledning.

FÖRSLAG PÅ KÄLLANGIVELSER:

Olofsson, Gunnar \& Anders Hylmö (20I7) ”Inledning till Karl Polanyis 'Ekonomin som inrättad process"” (s. 9-12),

Polanyi, Karl, Conrad M. Arensberg \& Harry W. Pearson (20I7 [1957]) "Ekonomins plats i samhället" (s. I3-I6),

Polanyi, Karl (2017 [1957]) "Ekonomin som inrättad process", i Arkiv. Tidskrift för samhällsanalys, nr 8, s. I7-46.

DOI: https://doi.org/I0.13068/2000-6217.8.I

(C) original: Free Press, Macmillan Publishing Company 1957

(C) svensk version: Författarna/Arkiv förlag \& tidskrift 2017 (publicerad 8 juni 20I7)

Artikeln distribueras enligt en upphovsrättslicens från Creative Commons:

Erkännande-Ickekommersiell-IngaBearbetningar 3.0 Unported, som medger fri ickekommersiell användning och spridning i oförändrat skick så länge källan anges. 
Arkiv. Tidskrift för samhällsanalys är en sakkunniggranskad vetenskaplig tidskrift för samhällsvetenskap och historia. Samtliga artiklar publiceras fritt tillgängliga på:

$$
\text { www.tidskriftenarkiv.se }
$$

Beständig länk, DOI: https://doi.org/IO.I3068/2000-62I7

Den här artikeln finns tillgänglig i följande format:

PDF \& HTML: via beständig länk, DOI: https://doi.org/IO.I3068/2000-62I7.8.I EPUB: ingår i e-boksutgåva av numret, ISBN: 978 9I 79242909

TRYCK: ingår i bokutgåva av numret, ISBN: 978 9I 7924 29I 6

Grafisk utformning och sidnumrering är identisk i pdf och tryck.

Samtliga artiklar i nr 8 (20I7) nås via beständig länk, DOI: https://doi.org/I0.13068/2000-6217.8

Arkiv. Tidskrift för samhällsanalys ISSN: 2000-62I7 (för elektronisk resurs) ISSN: 2000-6225 (för tryckta nummer)

ges ut av

Stiftelsen Arkiv för främjande och spridning av samhällsvetenskaplig och historisk forskning

\author{
genom \\ Arkiv förlag \& tidskrift \\ Box 1559 \\ SE-22I OI Lund \\ BESÖK: L Gråbrödersg 3 c, ipg \\ TEL: 046-I3 3920
}

ARKIV FÖRLAG: arkiv@arkiv.nu·www.arkiv.nu

TIDSKRIFTEN ARKIV: red@tidskriftenarkiv.se.www.tidskriftenarkiv.se

ANSVARIg UTGIVARE \& CHEFREDAKTÖR: Sven Hort

Administrativ RedaKtör: David Lindberg Redaktörer: Paavo Bergman, Per Dannefjord, Lisa Kings,

Zhanna Kravchenko, Anna-Maria Sarstrand Marekovic 


\title{
KLASSIKERAVDELNING
}

\section{Ekonomin som inrättad process}

\author{
KARL POLANYI
}

Gunnar Olofsson \& Anders Hylmö

Inledning 9

Karl Polanyi, Conrad M. Arensberg \& Harry W. Pearson

Ekonomins plats $i$ samhället $\mathrm{I} 3$

Karl Polanyi

Ekonomin som inrättad process $\mathrm{I} 7$ 



\title{
Inledning till Karl Polanyis "Ekonomin som inrättad process"
}

\author{
GUNNAR OLOFSSON \& ANDERS HYLMÖ
}

År 1989 gav Arkiv förlag ut en översättning av Karl Polanyis klassiska arbete från 1944, The Great Transformation, med titeln Den stora omdaningen. Den boken är nu inne på sin tredje upplaga. Det är också Polanyis mest kända verk.

Under senare år har intresset för Polanyis arbeten och inte minst för hans analys av den moderna, kapitalistiska samhällsordningen vuxit närmast explosionsartat. Den stora omdaningen finns översatt till en rad språk. Flera viktiga arbeten om Polanyis liv och verk har nyligen kommit ut. Det finns ett särskilt institut som bär hans namn (Karl Polanyi Institute of Political Economy) och som ägnas honom och hans verk. Där finns bland annat hans arkiv med efterlämnade papper - brev, manuskript, utkast med mera. Hans dotter, Kari Polanyi Levitt, professor emeritus i ekonomi vid McGill-universitetet i Montreal, har förvaltat hans intellektuella kvarlåtenskap och energiskt verkat för att sprida kunskap om Karl Polanyi och hans verk.

Den stora omdaningen är utan tvekan Karl Polanyis huvudarbete. Han utvecklade under 1940- och 1950-talet tankegångar från den boken i olika uppsatser och bokkapitel och i arbetet med ett stort och ambitiöst bokmanus (The Livelihood of Man). Ett känt exempel är hans artikel från 1947 om den föråldrade marknadsmentaliteten ("Our obsolete market mentality"). Paradoxalt nog är det just denna marknadsmentalitet som djupt har präglat de sista trettiofem årens samhällsutveckling och 
ekonomiska ideologi - och som i sin tur gjort Polanyis arbeten alltmer uppmärksammade och aktuella. ${ }^{1}$

Tidskiften Arkiv publicerar nu en översättning av Karl Polanyis kapitel "The economy as instituted process". Den texten skrev Polanyi som en teoretisk sammanfattning till boken Trade and Market in the Early Empires (1957) som han sammanställde tillsammans med Conrad M. Arensberg och Harry W. Pearson. (De tre redaktörernas korta inledning till den teoretiska avdelningen, "The place of economies in societies", har även den översatts och ligger före själva huvudartikeln precis som i boken.) Detta kapitel torde vara den näst mest kända texten av Karl Polanyi. Det gav upphov till en bred och omfattande samhällsvetenskaplig debatt om spänningen mellan ekonomibegreppets två olika innebörder - dels som en samhällelig arena för tillverkning och fördelning av produkter och nyttigheter (det substantiella innehållet i ett samhälles ekonomi), dels som ett formaliserat tankesystem för rationell optimering av handlingar och resurser. Medan den första förståelsen av "det ekonomiska" syftar på de samhälleliga institutioner och processer varigenom mänskliga behov tillfredsställs på olika sätt i olika samhällen, syftar den andra förståelsen på den "ekonomiserande" handlingens problem som en rent logisk och förment universell relation mellan mål och knappa medel. De två sidorna av ekonomibegreppet bärs fram av sina respektive förespråkare, "substantivister" och "formalister".

Polanyis syfte med kapitlet om "Ekonomin som inrättad process" var att utveckla begrepp som mer precist kunde fånga de olika sätt varpå tillverkning, utbyte och fördelning av produkter i olika slags samhällen fungerade. Endast i det moderna marknadssamhället spelar den prisbildande marknadens logik huvudrollen i dessa processer, vilket också är anledningen till att de två betydelserna av "det ekonomiska" i dag sammanblandas. En grundläggande idé hos Polanyi är att ekonomin inte bara bör förstås som en process, utan att denna process också i varie-

I. "Our obsolete market mentality" publicerades i Commentary nr 3 I947, s. IO9-II7. En hårdför kritik av Polanyis begrepp och hans syn på marknaden som en historiskt avgränsad ekonomisk kategori har passande nog titeln "The obsolete 'anti-market' mentality: A critique of the substantive approach to economic anthropology". Den artikeln är skriven av Scott Cook och återfinns i American Anthropologist, ny följd, vol. 68, nr 2 I966, s. 323-345. 
rande utsträckning är inrättad, eller institutionaliserad, och inbäddad i en väv av andra institutioner - ekonomiska, politiska, religiösa, etc. - på en rad olika sätt genom historien. Polaynis begrepp om ekonomins institutionella inbäddning har under de senaste tre decennierna stått i centrum för den så kallade nya ekonomiska sociologin, där det kommit att förstås på olika sätt, ofta som motbild till den neoklassiska bilden av en asocial homo oeconomicus eller ekonomin som en universell autonom samhällssfär. ${ }^{2}$

Boken Trade and Market in the Early Empires hade sin bakgrund i ett långvarigt forskningsprojekt och tillhörande seminarieserie vid Columbia-universitetet i New York. Polanyi var knuten dit som lärare under åren 1947-1953. ${ }^{3}$ Syftet med projektet var att undersöka vilka former som handel och utbyte av varor och nyttigheter tagit sig i olika historiska sammanhang.

Polanyi hade redan i Den stora omdaningen diskuterat problemet med ekonomibegreppets två sidor, men då relativt kort och mest inriktad på olika former för fördelning och omfördelning. Den diskussionen för han i bokens kapitel 4. Där diskuterar Polanyi tre mekanismer och deras institutionella arrangemang för utbyte vid sidan av marknaden - ömsesidighet (reciprocity), omfördelning (redistribution) och hushållning inom en given social enhet (oikos).

Vad kan då Polanyis argument i den här texten tjäna till? I dag står en betydande del av den politiska och ideologiska kampen om det ska eller till och med ens kan - finnas några gränser för kapitalets och vinstlogikens utbredning i samhällskroppen. I strävan att utöka kapitalets och

2. För en diskussion om de olika sätt på vilka Polanyis begrepp om ekonomins inbäddning tolkats inom olika grenar av den nya ekonomiska sociologin, se Greta R. Krippner och Anthony S. Alvarez, "Embeddedness and the intellectual projects of economic sociology", från Annual Review of Sociology, vol. 33, nr I 2007, s. 219-240. En kartläggning av hur Polanyi själv använder begreppet inbäddning (embeddedness) i Den stora omdaningen finns i Gunnar Olofsson, "Embeddedness and integration”, i Ian Gough och Gunnar Olofsson (red.), Capitalism and Social Cohesion. Essays on Exclusion and Integration, London: Macmillan 1999, s. 38-60.

3. Han pendlade till New York från sitt hem i Kanada. Skälet var att hans hustru Ilona Duczynska - inte utan historiskt väl grundade skäl - var stämplad som kommunist av den amerikanska underrättelsetjänsten. 
marknadslogikens sfär sätts begrepp och institutioner som förkroppsligar idéer om valfrihet, incitament, vinstmotiv, kapitalavkastning med mera, i spel som varande på en gång självklara och allmängiltiga. Polanyis text är då en påminnelse om att man inte ska falla i fällan att automatiskt inordna all praktisk samhällsaktivitet som rör produktion och fördelning av produkter, nyttigheter och tjänster, alla ekonomiska och sociala institutioner, under ett och samma abstrakt rationella handlings- och tankesystem, marknadssamhällets och kapitalets logik.

\section{Lund $i$ april 2017}

\section{Bibliografi}

\section{Böcker av Karl Polanyi}

Polanyi, Karl (2012 [1944]) Den stora omdaningen. Marknadsekonomins uppgång och fall, inledning av Gunnar Olofsson, tredje ombrutna och översedda upplagan, Lund: Arkiv förlag.

Polanyi, Karl, Conrad M. Arensberg och Harry W. Pearson (red.) (1957) Trade and Market in the Early Empires. Economies in History and Theory, New York: Free Press.

Polanyi, Karl (1977) The Livelihood of Man, Harry W. Pearson (red.), New York: Academic Press.

\section{Några viktiga nyutkomna arbeten om Polanyi och hans verk}

Block, Fred och Margaret R. Somers (20I4) The Power of Market Fundamentalism. Karl Polanyis Critique, Cambridge: Harvard University Press.

Dale, Gareth (20I0) Karl Polanyi. The Limits of the Market, Cambridge: Polity.

Dale, Gareth (2016) Karl Polanyi. A Life on the Left. New York: Columbia University Press.

Dale, Gareth (2016) Reconstructing Karl Polanyi. Excavation and Critique. London: Pluto Press.

Ett urval av äldre litteratur av och om Polanyi finns noterade i Gunnar Olofssons inledning till Den stora omdaningen (2012 [1944]), s. 2I-23. Inledningen finns tillgänglig som pdf $\mathrm{i}$ anslutning till förlagets information om boken på sin hemsida, se www.arkiv.nu. Polanyis argument i "Ekonomin som inrättad process" åberopas i den debatt om substantivism och formalism som ställts samman i Tomas Gerholm (red.), Prolog till en marxistisk antropologi. En diskussion om teori och metod, Stockholm: PAN/Norstedt I97I. För vidare information om vad som pågår kring Karl Polanyis arbeten, se Karl Polanyi Institute of Political Economys hemsida: www.concordia.ca/research/polanyi.html. 


\title{
Ekonomins plats i samhället
}

\author{
KARL POLANYI, \\ CONRAD M. ARENSBERG \\ \& HARRY W. PEARSON
}

I dag är det få samhällsvetare som helt accepterar upplysningens naiva uppfattning att den primitiva människan gör upp om friheter och byter varor ute i vildmarken för att skapa ett samhälle och en ekonomi. Comtes, Quételets, Marx', Maines, Webers, Malinowskis, Durkheims och Freuds upptäckter spelade en viktig roll för framväxten av vår nuvarande insikt att den sociala processen är en väv av relationer mellan människan som biologisk enhet och den unika symbol- och teknikstruktur som ska trygga hennes existens. Men även om vi i denna mening har upptäckt samhällets realitet har den nya insikten inte frambringat någon samhällsvision som kan mäta sig med den traditionella bilden av atomistisk individualism. I kritiska ögonblick återfaller vi i de tidigare rationaliseringarna om människan som utilitaristisk atom. Och ingenstans är detta återfall mer uppenbart än i våra föreställningar om ekonomin. En samhällsvetare som ger sig i kast med ekonomin i någon av dess vitt skilda aspekter hämmas fortfarande av den hävdvunna uppfattningen att människan har en medfödd benägenhet att byta, växla och skifta ett ting mot ett annat. Och detta trots alla protester mot den "ekonomiska människan" och de återkommande försöken att ge ekonomin en social inramning.

Översättning av kapitlet "The place of economies in societies" i Karl Polanyi, Conrad M. Arensberg \& Harry W. Pearson (red.), Trade and Market in the Early Empires. Economies in History and Theory (Free Press 1957). 
Den ekonomiska rationalism vars arvingar vi är förutsätter en typ av handling som är unikt ekonomisk. I detta perspektiv konfronteras en aktör - en enskild människa, en familj, ett helt samhälle - med en naturlig miljö som bara långsamt kan frambringa sina livgivande element. Ekonomisk handling - eller mer exakt ekonomiserande handling, rationalitetens innersta väsen - betraktas då som ett sätt att disponera tid och energi så att man utifrån detta förhållande mellan människa och natur når så många mål som möjligt. Och ekonomin blir platsen för en sådan handling. Självfallet kan denna ekonomi i realiteten påverkas på flera olika sätt av andra faktorer av icke-ekonomisk karaktär, de må vara politiska, militära, konstnärliga eller religiösa. Den utilitaristiska rationalitetens kärna förblir dock mönstret för ekonomin.

Denna syn på ekonomin som en plats där olika enheter fördelar, sparar, säljer överskott och bildar priser växte fram ur I700-talets västerländska miljö, och den är förvisso relevant i marknadssystemets institutionella ordning eftersom de faktiska förhållandena där i stora drag uppfyller det ekonomistiska postulatets krav. Men kan vi från detta postulat sluta oss till att marknadssystemet är allmänt förekommande i den empiriska faktavärlden? Den formella ekonomins anspråk på historiskt generell tillämpbarhet innebär ett jakande svar på den frågan. I själva verket argumenteras det i denna ekonomi för att det finns ett virtuellt marknadssystem i varje samhälle, antingen det empiriskt existerar eller ej. All mänsklig ekonomi kan alltså betraktas som en potentiell utbuds-, efterfråge- och prismekanik, och de faktiska processerna, vilka de nu än är, kan förklaras utifrån denna begreppsvärld.

Om empirisk forskning någonsin ska kunna öka vår förståelse av den grundläggande funktion och den ställning som ekonomins olika former har i olika samhällen måste vi pröva relevansen av detta ekonomistiska postulat. Närmar vi oss den ekonomiska processen utifrån den nya kunskap vi har vunnit om samhällets verklighet, måste vi hävda att det inte råder något nödvändigt förhållande mellan ekonomiserande handling och en reellt existerande ekonomi. Ekonomins institutionella struktur behöver inte, som hos marknadssystemet, framtvinga ekonomiserande handlingar. Konsekvenserna av en sådan insikt kunde knappast vara mer långtgående för alla de samhällsvetenskaper som måste gripa sig an eko- 
nomin. Det krävs ingenting mindre än en helt ny utgångspunkt för analysen av den mänskliga ekonomin som social process.

I sökandet efter en ny början övergår vi nu från den ekonomiserande till den substantivistiska innebörden av termen "det ekonomiska", hur omodern den än kan tyckas vara. Det betyder inte att vi bortser från den populära användningen av termen där man förväxlar ekonomisering med materialitet: vi hävdar bara att denna vanliga förväxling har begränsad tillämpning. Har en människa inte mat att äta måste hon svälta, hon må vara rationell eller ej; men för hennes trygghet, ja, bildning, konst och religion krävs också materiella resurser: vapen, skolor, tempel av trä, sten eller stål. Detta faktum förbisågs naturligtvis aldrig. Gång efter annan ställdes krav på att "nationalekonomin" skulle grundas på människans materiella behovstillfredsställelse - å ena sidan hennes materiella behov, och å andra sidan medlen för att tillfredsställa hennes behov, antingen de var materiella eller ej.

Experterna är ense om att alla strävanden efter en sådan naturalistisk ekonomi har misslyckats. Anledningen är enkel. Ett rent naturalistiskt ekonomibegrepp kan inte ens tillnärmelsevis mäta sig med ekonomisk analys när det gäller att förklara livsuppehällets mekanik under ett marknadssystem. Och eftersom ekonomin i allmänhet likställdes med marknadssystemet tycktes dessa naiva försök att ersätta ekonomisk analys med ett naturalistiskt schema vara grundligt misskrediterade.

Men var detta ett avgörande argument mot användningen av ett substantivistiskt ekonomibegrepp inom samhällsvetenskapen? Inte alls. Man förbisåg bara att ekonomisk teori, ekonomisk analys eller nationalekonomi rätt och slätt bara är en av flera discipliner som sysslar med människans livsuppehälle ur en materiell synvinkel, det vill säga med ekonomin. I praktiken är den inte mer än ett studium av marknadsfenomen; förutom att innehålla rent allmänna påståenden är dess relevans för andra system än marknadssystemet, exempelvis planekonomi, försumbar. Kan den till exempel hjälpa antropologen att lösgöra ekonomin från den allmänna samhällsväven i ett släktskapssystem? I frånvaron av marknader och marknadspriser kan nationalekonomen inte vara till någon hjälp för den som studerar primitiva ekonomier; han kanske $\mathrm{i}$ stället rent av hindrar honom. Eller ta sociologen som står inför frågan 
om ekonomins skiftande plats i olika samhällen. Bara om vi håller oss till tider och områden där det existerar prisbildande marknader kan nationalekonomin ge honom värdefull orientering. Detta gäller ännu mer för ekonomhistorikern bortom de ynka få århundraden under vilka prisbildande marknader och därmed pengar som bytesmedel har blivit allmänt förekommande. Under förhistorisk tid, under människans tidigare historia, ja, som Karl Blücher var den förste att deklarera, under människans hela historia utom de senaste århundradena, har ekonomin varit organiserad på ett sätt som skilt sig från allt vad nationalekonomen har föreställt sig. Och skillnaden, börjar vi nu sluta oss till, kan reduceras till en enda kärnpunkt: människan har inte haft något system av prisbildande marknader. Alla de ekonomiska disciplinerna förenas av sitt gemensamma intresse för den process genom vilken de materiella behoven tillfredsställs. Det går bara att lokalisera denna process och undersöka dess verksamhet om man förskjuter tonvikten från det rationella handlandet till rörelsemönstren hos de varor och personer som faktiskt utgör ekonomin.

Att övergå till en ny begreppsram är en sak inom naturvetenskapen och en helt annan inom samhällsvetenskapen. Det är som att bygga om ett hus - grund, väggar, inredning, allt - samtidigt som man bor kvar i det. Man måste göra sig kvitt den inrotade föreställningen att ekonomin är ett erfarenhetsområde som människan alltid med nödvändighet har varit medveten om. Ekonomins fakta var, för att använda en metafor, ursprungligen inbäddade i situationer som inte i sig själva var av ekonomisk natur, eftersom varken målen eller medlen i första hand var materiella. Ekonomibegreppet fick sin definitiva form under tidens och historiens gång. Men varken tiden eller historien har gett oss de begreppsverktyg som krävs för att tränga in i den härva av sociala relationer som ekonomin är inbäddad i. Detta är uppgiften för det som här kallas institutionell analys. 


\title{
Ekonomin som inrättad process
}

\author{
KARL POLANYI
}

Vårt huvudsyfte i detta kapitel är att bestämma den konsistenta innebörden av begreppet "det ekonomiska" inom alla samhällsvetenskaperna.

Alla sådana försök måste utgå från det enkla erkännandet av det faktum att "det ekonomiska", när det används om mänskliga verksamheter, förenar två olika innebörder som har var sina självständiga rötter. Jag kommer att kalla dem för den substantivistiska och den formella innebörden.

Den substantivistiska innebörden härleds ur människans beroende av naturen och sina medmänniskor för sitt livsuppehälle. Den syftar på utbytet med den naturliga och den sociala miljön såtillvida som detta förser henne med medlen för den materiella behovstillfredsställelsen.

Den formella innebörden härleds ur den logiska karaktär som förhållandet mellan mål och medel har, såsom framgår av orden "ekonomisk" och "ekonomiserande". Den syftar på en bestämd valsituation, där ett val mellan olika användningar av medlen framtvingas av en otillräcklighet hos dessa medel. Om man kallar de regler som bestämmer valet av medel för det rationella handlandets logik, kan man med en improviserad term beteckna denna form av logik som formell ekonomi.

De två grundbetydelserna av "det ekonomiska", den substantivistiska och den formella, har ingenting gemensamt. Den senare härrör från logi-

Översättning av kapitlet "The economy as instituted process" i Karl Polanyi, Conrad M. Arensberg \& Harry W. Pearson (red.), Trade and Market in the Early Empires. Economies in History and Theory (Free Press 1957). 
ken, den förra från fakta. Den formella innebörden förutsätter en samling regler som gäller valet mellan alternativa användningar av otillräckliga medel. Den substantivistiska innebörden förutsätter varken val eller otillräcklighet hos medlen; människans livsuppehälle kan, men behöver inte, inbegripa valets nödvändighet, och om det blir fråga om ett val behöver det inte framkallas av den begränsande effekt som medlens "knapphet" har; i själva verket är några av de viktigaste fysiska och sociala villkoren för livets uppehälle, som tillgång på luft och vatten eller en moders kärlek till sitt lilla barn, i regel inte särskilt begränsande. De tvingande krafter som verkar i det ena och i det andra fallet skiljer sig åt, liksom syllogismens kraft skiljer sig från tyngdkraften. I det ena fallet är det fråga om medvetandets lagar, i det andra naturens. De två innebörderna kan inte vara mer skilda - semantiskt ligger de i motsatta kompassriktningar.

Jag påstår att det bara är den substantivistiska innebörden av "det ekonomiska” som kan frambringa de begrepp som samhällsvetenskaperna behöver för att undersöka det förflutnas och nutidens empiriska ekonomier. Den allmänna referensram som jag försöker konstruera kräver därför en behandling av ämnet i substantivistiska termer. Det omedelbara hindret i vår väg ligger, som redan antytts, i en föreställning om ”det ekonomiska" där de två innebörderna, den substantivistiska och den formella, naivt blandas ihop. En sådan sammansmältning av innebörder är naturligtvis oantastlig så länge man förblir medveten om dess begränsande effekter. Men i det aktuella begreppet "det ekonomiska” smälter uppehälles- och knapphetsaspekterna samman utan att man är tillräckligt medveten om de faror för det klara tänkandet som ligger i denna sammansmältning.

Denna begreppsförening uppstod ur logiskt tillfälliga omständigheter. Under de två senaste århundradena har människornas livsuppehälle i Västeuropa och Nordamerika organiserats på ett sådant sätt att valets regler råkat vara sällsynt tillämpliga. Denna form av ekonomi bestod av ett system av prisbildande marknader. Eftersom de byteshandlingar som utförs i ett sådant system drar in aktörerna i val som framkallas av en otillräcklighet hos medlen kunde systemet reduceras till ett mönster som lämpligen studerades med hjälp av metoder baserade på den formella innebörden av "det ekonomiska”. Så länge ekonomin kon- 
trollerades av ett sådant system skulle de formella och substantivistiska innebörderna i praktiken sammanfalla. Lekmän accepterade detta sammansatta begrepp som en självklar sak; Marshall, Pareto och Durkheim stödde i lika hög grad användningen av begreppet. Endast Menger framförde kritik i sitt postuma verk, men varken han eller Max Weber, eller Talcott Parsons efter honom, begrep distinktionens betydelse för sociologisk analys. Det tycktes faktiskt inte finnas något giltigt skäl att skilja mellan de två grundbetydelserna, som alltså var tvungna att sammanfalla i praktiken.

Medan det därför skulle ha varit rent pedanteri att i vanligt tal skilja mellan de två innebörderna av "det ekonomiska" visade sig deras sammansmältning i ett enda begrepp ändå bli ett fördärv för samhällsvetenskaperna i metodologiskt hänseende. Nationalekonomin utgjorde naturligtvis ett undantag eftersom dess begrepp måste vara ganska realistiska under ett marknadssystem. Men antropologen, sociologen eller historikern, som alla studerade ekonomins plats i det mänskliga samhället, konfronterades inte bara med marknader utan med en mängd andra institutioner i vilka människans livsuppehälle var inbäddat. Dess problem kunde inte angripas med hjälp av en analytisk metod avsedd för en speciell form av ekonomi, som var beroende av specifika marknadselements närvaro. ${ }^{\mathrm{I}}$

Därmed anges också grovt den linje som jag kommer att följa i min argumentering.

Jag börjar med att närmare undersöka de begrepp som kan härledas ur de två innebörderna av "det ekonomiska", först den formella inne-

I. Okritisk användning av det sammansätta begreppet gav upphov till vad som skulle kunna kallas "det ekonomistiska felslutet", som bestod i att ekonomin uppfattades som identisk med sin marknadsform. Från Hume och Spencer till Frank H. Wright och Northrop har samhällsvetenskaperna begränsats av detta varje gång de berört ekonomi. Lionel Robbins' essä (1932) förvrängde problemet på ett ödesdigert sätt, fast den är användbar för ekonomer. Inom antropologin innebar Melville Herskovits' senast verk (1952) ett steg tillbaka efter hans banbrytande insats 1940. [De verk Polanyi hänvisar till är: Lionel Robbins, An Essay on the Nature and Significance of Economic Science, London: Macmillan 1932; Melville Herskovits, Economic Anthropology. A Study in Comparative Economics, New York: Alfred A. Knopf 1952; idem, The Economic Life of Primitive Peoples, New York: Alfred A. Knopf i940. Red. anm.] 
börden och sedan den substantivistiska. Det bör därefter visa sig möjligt att beskriva de empiriska ekonomierna, antingen de är primitiva eller arkaiska, i enlighet med hur den ekonomiska processen är inrättad. Handelns, pengarnas och marknadens tre institutioner kommer att utgöra vårt testfall. Eftersom de tidigare bara har definierats i formella termer har det varit omöjligt att utgå från något annat perspektiv än marknadsperspektivet. Genom att behandla dem i substantivistiska termer bör jag kunna närma mig den eftersträvade allmänna referensramen.

\section{Den formella och den substantivistiska innebörden av "det ekonomiska"}

Låt oss undersöka de formella begreppen med utgångspunkt i det sätt på vilket det rationella handlandets logik ger upphov till formell ekonomi och denna i sin tur leder till ekonomisk analys.

Rationellt handlande definieras här som val av medel i relation till ett mål. Som medel räknas allt som tjänar detta mål, i kraft av antingen naturens lagar eller spelets regler. "Rationell” hänför sig följaktligen varken till målen eller till medlen utan till relationen mellan dem. Det förutsätts exempelvis inte att det är mer rationellt att vilja leva än att vilja dö eller, i det förra fallet, mer rationellt att eftersträva ett långt liv med hjälp av vetenskap än med hjälp av vidskepelse. För oavsett målet är det rationellt att välja sina medel i enlighet med detta, och i fråga om medlen skulle det inte vara rationellt att handla enligt något annat kriterium än det som man råkar tro på. Således är det för självmördaren rationellt att välja de medel som leder till hans död, och om han tror på svart magi att betala en häxdoktor för att uppnå detta mål.

Det rationella handlandets logik gäller följaktligen för alla tänkbara medel och mål och omfattar en nästan oändlig mängd olika mänskliga intressen. Inom schack eller teknik, inom det religiösa livet eller filosofin, kan målen variera från de mest triviala frågor till de mest svårtillgängliga och komplicerade. På liknande sätt förhåller det sig på ekonomins område, där målen kan variera från att tillfälligt släcka törsten till att uppnå en hög ålder, medan motsvarande medel omfattar ett glas vatten och en kombinerad förlitan på barnens omsorg och ett sunt friluftsliv. 
Under förutsättning att valet framkallas av en otillräcklighet hos medlen övergår det rationella handlandets logik till den variant av valteori som här har kallats formell ekonomi. Den står ännu inte i något logiskt förhållande till den mänskliga ekonomins begrepp men har tagit ett steg närmare. Den formella ekonomin hänför sig, som jag redan har sagt, till en valsituation som uppstår ur medlens otillräcklighet. Detta är det så kallade knapphetspostulatet. Det förutsätter för det första otillräcklighet hos medlen och för det andra att valet framkallas av denna otillräcklighet. Medlens otillräcklighet i förhållande till målen fastställs med hjälp av en enkel "öronmärkningsoperation" som visar om medlen räcker till eller ej. För att otillräckligheten ska framkalla ett val måste det finnas mer än en användning av medlen och målen måste vara graderade; det måste alltså finnas åtminstone två olika mål placerade i prioriteringsordning. Båda villkoren är faktiska. Det spelar ingen roll om det råkar vara en konventionell eller teknisk anledning till att medlen används på ett visst sätt; detsamma gäller för målens gradering.

Har man på så sätt definierat val, otillräcklighet och knapphet i operationella termer är det lätt att inse att precis som det finns val av medel utan otillräcklighet finns det otillräcklighet hos medel utan val. Ett val kan framkallas av att man föredrar det rätta framför det orätta (moraliskt val), eller när man står vid en korsväg och bestämmelseorten kan nås via två eller flera vägar som har identiska fördelar och nackdelar (operationellt framkallat val). Inte i något av fallen skulle ett överflöd av medel minska svårigheten att välja, snarare tvärtom. Självklart kan knapphet existera vid nästan alla former av rationellt handlande. All filosofi är inte fantasifull kreativitet, det kan också vara fråga om att på bästa sätt utnyttja förutsättningarna. Eller, för att återvända till det mänskliga livsuppehällets sfär, i vissa kulturer tycks bristsituationer nästan vara ett undantag medan de i andra verkar vara förfärande vanliga. I båda fallen är förekomsten eller frånvaron av knapphet en fråga om fakta, antingen knappheten beror på Naturen eller på Lagen.

Sist men inte minst har vi den ekonomiska analysen. Denna disciplin uppstår genom att den formella ekonomin tilllämpas på en ekonomi av bestämd typ, nämligen ett marknadssystem. Ekonomin förkroppsligas här i institutioner som får individernas val att skapa de samverkande 
rörelser som utgör den ekonomiska processen. Detta sker genom att prisbildande marknader blir vanligt förekommande. Alla varor och tjänster, inklusive användningen av arbete, jord och kapital, kan köpas på marknader och har därför ett pris; alla former av inkomster härrör från försäljningen av varor och tjänster - löner, jordränta och penningränta framstår bara som olika prisexempel beroende på vad som säljs. Genom det allmänna införandet av köpkraft som förvärvsmedel förvandlas den process som ska tillfredsställa behov till en fördelning av otillräckliga medel med alternativa användningar, det vill säga pengar. Därav följer att både förutsättningarna för valet och dess konsekvenser kan kvantifieras i form av priser. Det kan hävdas att den formella angreppsmetoden genom att särskilt koncentrera sig på priset som ekonomiskt faktum erbjuder en total beskrivning av ekonomin, där denna förutsätts vara bestämd av val som framkallas av en otillräcklighet hos medlen. De begreppsverktyg med vars hjälp vilka detta sker utgör disciplinen ekonomisk analys.

Av detta följer vissa gränser inom vilka den ekonomiska analysen kan visa sig vara effektiv som metod. Om det ekonomiska tillskrivs en formell innebörd blir ekonomin en rad ekonomiseringshandlingar, det vill säga val framkallade av bristsituationer. Medan reglerna som styr sådana handlingar är universella, är den utsträckning i vilken reglerna kan tillämpas på en bestämd ekonomi beroende av huruvida denna ekonomi faktiskt är en rad sådana handlingar. För att ge kvantitativa resultat måste de positions- och tillägnelserörelser som utgör den ekonomiska processen framstå som funktioner av sociala handlingar i förhållande till otillräckliga medel och inriktade på att bilda priser. En sådan situation råder enbart under ett marknadssystem.

Den formella ekonomins förhållande till den mänskliga ekonomin är i själva verket tillfälligt. Utanför ett system av prisbildande marknader förlorar den ekonomiska analysen mycket av sin relevans som metod för undersökning av ekonomins funktionssätt. Den centralplanerade ekonomin, som vilar på icke-marknadspriser, är ett välkänt exempel.

Källan till det substantivistiska begreppet är den empiriska ekonomin. Den kan kort (om än inte särskilt lockande) definieras som en process av samverkan mellan människan och hennes miljö som inrättats för att garantera ständig tillgång på behovstillfredsställande materiella 
medel. Behovstillfredsställelsen är "materiell” om den innebär användning av materiella medel för att uppfylla ett mål; vid en bestämd typ av fysiologiska behov, såsom behov av mat eller husrum, använder man sig bara av så kallade tjänster.

Ekonomin är alltså en inrättad process. Två begrepp gör sig bemärkta: "process" och "inrättande". Låt oss se hur de kompletterar vår referensram.

Process tyder på en analys i rörelsetermer. Rörelserna hänför sig till förändringar i position eller tillägnelse eller både och. De materiella elementen kan med andra ord förändra sin situation antingen genom att ändra position eller genom att byta ägare; dessa annars mycket olika förändringar kan följas åt eller gå i skilda riktningar. De båda rörelseformerna kan inom sig sägas uttömma de möjligheter som ryms i den ekonomiska processen som naturligt och socialt fenomen.

Positionsrörelser omfattar utom transporter även produktion, för vilken föremålens förflyttning i rummet är lika viktig. Varorna är av en lägre eller högre ordning beroende på vilken nytta de har för konsumenterna. I denna berömda "varuordning" sätts konsumtionsvaror mot produktionsmedel beroende på om de tillfredsställer behoven direkt eller bara indirekt genom att kombineras med andra varor. Denna typ av rörelse hos elementen utgör en väsentlig del av ekonomin i substantivistisk mening, det vill säga produktionen.

Tillägnelserörelsen styr både vad som brukar kallas varornas cirkulation och varornas hantering. I det förra fallet uppstår rörelsen ur transaktioner, i det senare ur dispositioner. Följaktligen är transaktionen en tillägnelserörelse mellan olika parter, medan dispositionen är en ensidig handling till vilken bestämda tillägnelserörelser är knutna, genom vanans eller lagens makt. Med part menas här såväl offentliga organ och tjänster som privata personer och företag; skillnaden mellan dem är främst en fråga om inre organisation. Det bör dock noteras att man under I80o-talet vanligen associerade privata parter med transaktioner medan offentliga parter i allmänhet tillskrevs dispositioner.

Med detta val av begrepp följer ytterligare definitioner. Sociala verksamheter kan, i den mån de utgör en del av processen, kallas ekonomiska; institutioner kallas så i den mån de innehåller en koncentration 
av sådana verksamheter; alla processens komponenter kan betraktas som ekonomiska element. Dessa element kan lämpligen indelas i ekologiska, tekniska och samhälleliga element beroende på om de i första hand tillhör den naturliga omgivningen, den mekaniska utrustningen eller den mänskliga miljön. Genom att lägga en processaspekt på ekonomin kan jag således foga en rad begrepp, gamla som nya, till min referensram.

Ändå skulle denna process inte ha någon allmän realitet om den reducerades till elementens mekaniska, biologiska och psykologiska samverkan. Den innehåller inte mer än det mest rudimentära av produktions- och transportprocesserna, liksom av förändringarna i tillägnelseförhållandena. Utan någon som helst antydan om de samhälleliga villkor ur vilka individernas motiv härrör skulle det inte finnas mycket, om ens något, som upprätthöll rörelsernas ömsesidiga beroende och de återkommande mönster som processens enhet och stabilitet bygger på. Naturens och mänsklighetens samverkande element skulle inte bilda någon sammanhängande eller strukturell enhet som kunde sägas ha en funktion i samhället eller äga en historia. Processen skulle sakna just de kvaliteter som får både det vardagliga tänkandet och vetenskapen att betrakta frågorna om det mänskliga livsuppehället som ett område av såväl utomordentligt praktiskt intresse som teoretiskt och moraliskt värde.

Därför får ekonomins institutionella aspekt en oerhörd betydelse. Det som inträffar på processnivån mellan jorden och människan när hon hackar i marken eller vid transportbandet när en bil tillverkas är vid första påseendet bara en förening av mänskliga och icke-mänskliga rörelser. Ur en institutionell synvinkel refererar det bara till termer som arbete och kapital, hantverk och fackförening, ökande och minskande tempo, spridande av risker och andra semantiska enheter från det sociala sammanhanget. När det exempelvis gäller att välja mellan kapitalism och socialism väljer man mellan två olika sätt att införa ny teknik i produktionsprocessen. På den principiella nivån inbegriper också industrialiseringen av underutvecklade länder å ena sidan alternativa tekniker och å andra sidan alternativa metoder för att införa dem. Vår begreppsdistinktion är väsentlig för varje förståelse av det ömsesidiga beroende men också den relativa självständighet som präglar förhållandet mellan teknik och institutioner. 
Att den ekonomiska processen är inrättad ger den enhet och stabilitet; det skapar en struktur med en bestämd funktion i samhället; det förändrar processens plats i samhället och ger därmed ökad betydelse åt dess historia; det koncentrerar intresset på värderingar, motiv och politik. Enhet och stabilitet, struktur och funktion, historia och politik ger ett operationellt uttryck för innehållet i vårt påstående att den mänskliga ekonomin är en inrättad process.

Den mänskliga ekonomin är alltså inbäddad och invävd i institutioner, ekonomiska såväl som icke-ekonomiska. Det är väsentligt att man också inbegriper de icke-ekonomiska institutionerna. Religionen eller den politiska styrelseformen kan nämligen vara lika viktig för ekonomins struktur och funktion som penninginstitutionerna eller tillgången på redskap och maskiner som lättar arbetets möda.

När man studerar den skiftande plats som ekonomin intar i samhället studerar man därför helt enkelt hur den ekonomiska processen inrättas vid olika tidpunkter och på olika platser. Detta kräver en speciell verktygslåda.

\section{Ömsesidighet, omfördelning och utbyte}

Ett studium av hur empiriska ekonomier är inrättade bör utgå från det sätt på vilket ekonomin får enhet och stabilitet, det vill säga det ömsesidiga beroende och de återkommande rörelser som karakteriserar ekonomins delar. Detta sker genom en kombination av några få mönster som kan kallas integrationsformer. Eftersom de förekommer sida vid sida på olika nivåer och i olika sektorer av ekonomin kan det ofta vara omöjligt att peka ut en av dem som dominerande för att därigenom klassificera de empiriska ekonomierna. Men genom att differentiera mellan olika sektorer och nivåer av ekonomin erbjuder dessa former en möjlighet att beskriva den ekonomiska processen i jämförelsevis enkla termer så att man därmed får ett visst mått av ordning i dess oändliga variationer.

Empiriskt finner vi att huvudmönstren är ömsesidighet, omfördelning och utbyte. Ömsesidighet betecknar rörelser mellan motsvarande positioner i symmetriska grupperingar; omfördelning gäller tillägnelserörelser in till och ut från ett centrum; utbyte syftar här på de rörelser 
som förekommer mellan "parterna” i ett marknadssystem. Ömsesidigheten förutsätter alltså en ram av symmetriskt ordnade grupperingar, omfördelningen kräver ett visst mått av centralt maktorgan i gruppen, och utbytet fordrar ett system av prisbildande marknader för att kunna skapa integration. Det är tydligt att de olika integrationsmönstren förutsätter att de stöds av bestämda institutioner.

Här kan ett visst klarläggande vara välkommet. Begreppen ömsesidighet, omfördelning och utbyte, som jag låter syfta på mina integrationsformer, får ofta beteckna relationer mellan personer. Det kan alltså ytligt sett verka som om integrationsformerna bara återspeglade aggregat av olika former av individuellt beteende. Om ömsesidighet mellan individer var vanligt förekommande skulle en ömsesidig integration framträda; där fördelning bland individer var vanlig skulle omfördelande integration existera; på liknande sätt skulle återkommande byteshandlingar mellan individer resultera $\mathrm{i}$ utbyte som en form av integration. Om det vore på det sättet skulle våra integrationsmönster verkligen inte vara mer än enkla aggregat av motsvarande former av beteende på individnivå. Jag betonade visserligen att den integrerande effekten förutsatte närvaron av bestämda institutionella arrangemang, såsom symmetriska organisationer, centralpunkter och marknadssystem. Sådana arrangemang tycks utgöra ett rent aggregat av just de personliga mönster vars slutliga effekter de förutsätts bestämma. Det avgörande är dock att rena aggregat av ifrågavarande personliga beteenden inte av sig själva framkallar sådana strukturer. Ett ömsesidigt beteende bland individer integrerar ekonomin endast om symmetriskt organiserade strukturer, som exempelvis ett symmetriskt system av släktskapsgrupper, är givna. Men ett släktskapssystem uppstår aldrig som resultat av ett rent ömsesidigt beteende på den personliga nivån. På liknande sätt förhåller det sig med omfördelningen. Den förutsätter närvaron av ett fördelande centrum i samhället, men ett sådant centrum organiseras och sanktioneras inte bara därför att det ofta förekommer fördelningsaktiviteter mellan individerna. Slutligen gäller detsamma för marknadssystemet. Byteshandlingar på den personliga nivån framkallar priser bara om de förekommer i ett system av prisbildande marknader, ett institutionellt arrangemang som ingenstans skapas enbart genom slumpartade byteshandlingar. Jag vill därmed naturligtvis inte antyda att sådana 
stödjande mönster är resultatet av några mystiska krafter som verkar utanför det personliga eller individuella beteendets område. Jag hävdar bara att om det individuella beteendets sociala verkningar i ett givet fall beror på närvaron av bestämda institutionella förhållanden, är dessa förhållanden inte av den anledningen ett resultat av det personliga beteendet i fråga. Ytligt sett kan det verka som om det stödjande mönstret är resultatet av en ansamling av motsvarande former av personliga beteenden, men det är ovillkorligen en helt annan form av beteende som skapar de avgörande organisationsformerna och giltighetsvillkoren.

Den förste som, såvitt jag vet, kom på det faktiska sambandet mellan ömsesidigt beteende bland individer och givna symmetriska grupperingar var antropologen Richard Thurnwald i en empirisk studie från I9I5 av äktenskapssystemet hos banarostammen på Nya Guinea. Bronislaw Malinowski förutsåg ett tiotal år senare, i anslutning till Thurnwald, att man regelmässigt skulle finna att socialt relevant ömsesidighet vilade på symmetriska former av grundläggande social organisation. Hans egen beskrivning av trobriandernas släktskapssystem och kulahandel bekräftade detta. Jag fullföljde själv dessa tankar men betraktade symmetri som bara ett av flera stödjande mönster. Till ömsesidigheten fogade jag omfördelningen och utbytet som ytterligare former av integration; på liknande sätt fogade jag till symmetrin centralmakten och marknaden som andra exempel på institutionellt stöd. Så framkom mina integrationsformer och stödjande strukturmönster.

Detta bör bidra till att förklara varför ett beteende bland individer i den ekonomiska sfären så ofta är oförmöget att ge den förväntade samhälleliga effekten då bestämda institutionella förutsättningar saknas. Bara i en symmetriskt organiserad miljö kommer det ömsesidiga beteendet att resultera i ekonomiska institutioner av betydelse; bara där fördelningscentrum har upprättats kan individuella fördelningsaktiviteter åstadkomma en omfördelande ekonomi; och bara i ett system av prisbildande marknader kommer individernas byteshandlingar att resultera i fluktuerande priser som integrerar ekonomin. Annars kommer sådana byteshandlingar att förbli ineffektiva och tenderar därför att inte inträffa. Om de ändå, på ett slumpartat sätt, inträffade skulle en våldsam känsloreaktion sätta in, som vore det oanständiga eller förrädiska handlingar, 
eftersom handel mellan människor aldrig är något känslomässigt likgiltigt beteende eller tolereras av opinionen om det sker utanför de godkända kanalerna.

Låt oss nu återvända till våra integrationsformer. En grupp som medvetet åtog sig att organisera sina ekonomiska förhållanden på ömsesidighetens grund skulle för att förverkliga detta syfte vara tvungen att klyva sig i undergrupper vars medlemmar kunde identifiera sig som sådana. Medlemmar av grupp A skulle då kunna upprätta ett ömsesidigt förhållande med sina motparter i grupp B och vice versa. Men symmetri begränsar sig inte till tudelning. Tre, fyra eller fler grupper kan vara symmetriska i relation till två eller flera axlar; dessutom behöver gruppmedlemmarna inte samverka med varandra utan kan göra det med motsvarande medlemmar av en tredje grupp till vilka de står i ett jämförbart förhållande. En trobriandisk man har ansvar för sin systers familj. Men han bistås inte av systerns make utan, om han är gift, av sin egen hustrus bror, som är medlem av en tredje familj, som är placerad på motsvarande sätt.

Aristoteles lärde att mot varje slag av gemenskap (koinonia) svarade en form av tillgivenhet (flia) bland dess medlemmar som uttrycktes i ömsesidighet (antipepontos). Detta gällde både för mer permanenta gemenskaper, som familjer, stammar eller stadsstater, och för mindre permanenta gemenskaper som kan ingå i och underordnas de förra. Med våra termer innebär detta en tendens hos de större gemenskaperna att utveckla en mångsidig symmetri i förhållande till vilken ett ömsesidigt beteende kan utvecklas i de underordnade gemenskaperna. Ju mer medlemmarna känner sig dragna till varandra, desto mer benägna blir de att utveckla ömsesidiga attityder till specifika förhållanden som är begränsade i rummet, tiden eller på annat sätt. Släktskap, grannskap eller totem tillhör de mer permanenta och omfattande grupperingarna; inom deras ram skapar frivilliga och halvt frivilliga sammanslutningar av militär, yrkesmässig, religiös eller social karaktär situationer, där det åtminstone tillfälligtvis eller i förhållande till en given plats eller en typisk belägenhet bildas symmetriska grupperingar vars medlemmar utövar någon sorts ömsesidighet.

Ömsesidigheten som integrationsform vinner mycket i styrka genom sin förmåga att utnyttja både omfördelning och utbyte som underordnade metoder. Ömsesidighet kan uppnås genom att arbetsbördan delas 
enligt bestämda fördelningsregler, som när man åtar sig saker i tur och ordning. På liknande sätt uppnås ömsesidighet ibland genom utbyte i fastställda proportioner till förmån för den som råkar ha brist på någon nödvändighetsvara - en grundläggande institution i forntidens österländska samhällen. I ekonomier utan marknad förekommer i själva verket båda dessa former av integration - ömsesidighet och omfördelning - vanligen tillsammans.

Omfördelning existerar inom en grupp i den utsträckning som fördelningen av varor är samlad på en hand och sker med stöd av vana, lag eller centrala ad hoc-beslut. Ibland innebär det en fysisk insamling i förening med lagring och omfördelning; vid andra tillfällen är "insamlingen" inte fysisk utan sker enbart som tillägnelse, det vill säga som rätt att fysiskt förfoga över varorna. Omfördelning sker av många skäl och på alla kulturnivåer, från den primitiva jägarstammen till de väldiga lagringssystemen i forntidens Egypten, Sumer, Babylonien eller Peru. I stora länder kan skillnader i jordmån och klimat göra en omfördelning nödvändig; i andra fall framkallas den av skillnader i tiden, som mellan skörd och konsumtion. Vid jakt skulle varje annan fördelningsmetod leda till upplösning av horden eller skaran eftersom endast "arbetsdelning i samarbete" här kan garantera resultat; en omfördelning av köpkraften kan värdesättas för sin egen skull, det vill säga enligt vissa samhällsideal som i den moderna välfärdsstaten. Principen förblir densamma: insamling till och fördelning från ett centrum. Omfördelning kan också tillämpas i en grupp som är mindre än samhället, såsom hushållet eller godset, alldeles oavsett hur ekonomin som helhet är integrerad. De mest kända exemplen är den centralafrikanska kraalen, hebréernas patriarkala hushåll, den grekiska lantegendomen på Aristoteles tid, den romerska familjen, det medeltida godset eller det typiska stora bondehushållet innan spannmål började säljas allmänt på en marknad. Men det är bara i ett jämförelsevis utvecklat jordbrukssamhälle som det är möjligt att genomföra en hushållning och då i ganska generell mening. Den "småfamilj” som existerade allmänt dessförinnan var inte inrättad i ekonomiskt syfte utom vad gällde viss matlagning - nyttjandet av betesmark, jord eller boskap styrdes alltjämt av omfördelande eller ömsesidiga metoder på en högre nivå än familjens. 
ARKIV $\mid$ NR 8

Även omfördelningen tenderar att integrera grupper på alla nivåer och i alla grader av beständighet, från staten själv till enheter av tillfällig karaktär. Och precis som för ömsesidigheten gäller här att ju mer sammanhållen den omspännande enheten är, desto mer varierande blir de underavdelningar där omfördelningen sker. Platon lärde att antalet medborgare i en stat skulle vara 5 040. Denna siffra var delbar på 59 olika sätt, inklusive delning med de tio första räkneorden. Den skulle, förklarade han, ge större spelrum när det gällde att fastställa skatter, bilda grupper för affärstransaktioner, fördela militära och andra bördor i turordning etc.

För att utbytet ska fungera som integrationsform krävs ett stödjande system av prisbildande marknader. Man bör därför skilja mellan tre slag av utbyte: den rent fysiska rörelsen när en vara byter plats och ägare (operationellt utbyte); den rörelse där man tillägnar sig varan till ett fastställt pris (beslutsutbyte) eller till ett pris som man har förhandlat om (integrationsutbyte). När det är fråga om utbyte till ett fastställt pris integreras ekonomin inte genom marknadsmekanismen utan genom de faktorer som bestämmer detta pris. Och de prisbildande marknaderna får i sin tur en integrerande funktion först om de kopplas samman i ett system som sprider priseffekterna till andra marknader än de direkt berörda.

Köpslagan har med rätta betraktats som det väsentliga elementet i ett förhandlingsbeteende. För att utbytet ska få en integrerande funktion måste var och en av parterna vara inriktad på att åstadkomma ett pris som är så gynnsamt som möjligt just för honom. Ett sådant beteende står i stark kontrast till det som utvecklas vid utbyte till ett fastställt pris. Tvetydigheten i begreppet "vinst" tenderar att dölja skillnaden. Utbyte till fastställt pris innebär inte mer än att båda parter gör just den vinst som förutsattes vid beslutet om utbyte; utbyte till fluktuerande priser syftar till en vinst som bara kan uppnås om det råder ett fientligt förhållande mellan parterna. Elementet av fiendskap i denna utbytesvariant är outrotligt, även om det ibland bara uppträder i försvagad form. Inget samhälle som vill skydda källan till solidaritet mellan sina medlemmar kan låta en latent fientlighet utvecklas kring en fråga som är så väsentlig för den fysiska existensen och därför kan väcka sådan spänd oro som livsmedelsförsörjningen. Detta förklarar varför man i primitiva och arkaiska 
samhällen allmänt har förbjudit transaktioner av vinstgivande karaktär kring livsmedel. Med det allmänt spridda förbudet mot köpslagan om så livsviktiga varor försvinner de prisbildande marknaderna automatiskt från de äldsta institutionernas sfär.

Traditionella ekonomiindelningar som grovt liknar en klassifikation enligt de dominerande integrationsformerna är belysande. Vad historiker brukar kalla "ekonomiska system" tycks helt passa in i detta mönster. Dominans för en integrationsform identifieras här med den grad i vilken den infogar jorden och arbetet i samhället. Det så kallade barbariska samhället karakteriseras av att jorden och arbetet integreras i ekonomin genom släktförbindelser. I det feodala samhället är det länspliktens band som bestämmer jordens och det därmed förbundna arbetets öde. I flodimperierna var det huvudsakligen templet eller palatset som fördelade och ibland omfördelade jorden; och det gällde också för arbetet, åtminstone i dess beroende form. Marknadens utveckling till en styrande kraft i ekonomin kan spåras i jordens och livsmedlens gradvisa mobilisering genom utbyte och arbetets förvandling till en vara som fritt kan köpas på marknaden. Detta kan bidra till att förklara relevansen av marxismens historiskt ohållbara stadieteori om slaveri, livegenskap och lönearbete - en indelning som härrörde från övertygelsen om att ekonomins karaktär bestämdes av arbetets ställning. Jordens integration i ekonomin borde dock knappast betraktas som mindre väsentlig.

I vilket fall som helst representerar integrationsformerna inga "stadier" i utvecklingen. Det är inte fråga om någon tidsföljd. Flera underordnade former kan existera vid sidan av den dominerande, som själv kan återkomma efter en tillfällig tillbakagång. Stamsamhällena utövar ömsesidighet och omfördelning, medan de arkaiska främst är omfördelande även om de i viss utsträckning kan tillåta utbyte. Ömsesidigheten, som spelar en dominerande roll i vissa melanesiska samhällen, förekommer som ett inte oviktigt om än underordnat inslag i de omfördelande arkaiska imperierna, där utrikeshandeln (bedriven genom gåvor och motgåvor) alltjämt främst organiseras enligt ömsesidighetens princip. Den återinfördes faktiskt under beteckningen lend-lease i stor skala under andra världskriget i samhällen där annars marknader och utbyte dominerade. Omfördelningen, den dominerande metoden i stamsamhället och 
i det arkaiska samhället och vid sidan om vilken utbytet spelar bara en mindre roll, fick stor betydelse under det romerska kejsardömets senare år och vinner faktiskt i dag terräng i några moderna industristater. Sovjetunionen är ett extremt exempel. Och omvänt gäller att marknader mer än en gång under den mänskliga historiens lopp har haft betydelse i ekonomin, fastän aldrig i territoriell skala eller med en institutionell omfattning som kan jämföras med I80o-talets. Men här kan återigen en förändring iakttas. Under 1900-talet fick marknaderna i och med att guldmyntfoten försvann inte alls samma globala inflytande som de haft under I8oo-talet - ett trendbrott som för övrigt återför oss till vår utgångspunkt, nämligen de begränsade marknadsdefinitionernas ökande otillräcklighet för samhällsvetaren i hans studium av det ekonomiska området.

\section{Handelsformer, penningbruk och marknadselement}

Det begränsande marknadsperspektivet påverkar starkt tolkningen av handels- och penninginstitutionerna: ofrånkomligt framträder marknaden som bytesplatsen, handeln som det faktiska utbytet och pengarna som bytesmedlet. Eftersom handeln styrs av priserna och priserna är en funktion av marknaden är all handel marknadshandel, precis som alla pengar är bytespengar. Marknaden är den skapande institution av vilken handeln och pengarna är funktioner.

Sådana föreställningar stämmer inte med antropologiska och historiska fakta. Handeln och vissa penningbruk är lika gamla som mänskligheten; marknaderna fick däremot inte betydelse förrän jämförelsevis sent $\mathrm{i}$ historien, även om det kan ha funnits möten av ekonomisk karaktär så tidigt som under yngre stenåldern. Prisbildande marknader, som ensamma konstituerar ett marknadssystem, existerade såvitt man vet först under antikens första årtusende och då bara i skuggan av andra integrationsformer. Men inte ens dessa väsentliga fakta kunde klarläggas så länge handel och pengar ansågs vara begränsade till utbytets integrationsform, som dess specifikt "ekonomiska" form. De långa perioder i historien då ömsesidighet och omfördelning integrerade ekonomin, och den väsentliga omfattning i vilken detta skedde även under modern tid, avfärdades genom en restriktiv terminologi. 
Betraktade som ett utbytessystem bildar handel, pengar och marknad ett odelbart helt. Deras gemensamma begreppsram är marknaden. Handeln framstår som en dubbelriktad rörelse av varor genom marknaden, och pengarna som kvantifierbara varor som används för indirekt utbyte $\mathrm{i}$ syfte att underlätta denna rörelse. Ett sådant betraktelsesätt måste leda till ett mer eller mindre tyst accepterande av den heuristiska princip enligt vilken man bör förutsätta marknader där det förekommer handel, och handel, och därför marknader, där det förekommer pengar. Detta medför naturligtvis att man ser marknader där det inte finns några och bortser från existerande handel och pengar därför att det råkar saknas marknader. Den samlade effekten måste bli att det skapas en stereotyp föreställning om ekonomier från mindre kända tider och platser, ungefär som ett konstgjort landskap med ingen eller föga likhet med originalet. En särskild analys av handel, pengar och marknader är därför på sin plats.

\section{Handelsformer}

I ett substantivistiskt perspektiv är handel en relativt fredlig metod för att anskaffa varor som inte finns på platsen. Den är för en grupp människor något yttre och liknar verksamheter som vi brukar förknippa med jaktexpeditioner, slavjakter eller piraträder. Avsikten är att anskaffa och transportera varor som finns på annan ort. Det som skiljer handeln från sökandet efter villebråd, byte, rov, sällsynta trädslag eller exotiska djur är rörelsens tvåsidighet, som också garanterar att den får en i stort sett fredlig och tämligen regelbunden karaktär.

Sett i ett utbytesperspektiv är handel varornas rörelse genom marknaden. Alla varor, som alltså tillverkas för att säljas, är potentiella handelsobjekt; en vara rör sig i ena riktningen, en annan i motsatta riktningen; rörelsen kontrolleras av priser: handel och marknad sammanfaller. All handel är marknadshandel.

Återigen kan handel liknas vid jakter, räder eller expeditioner som utförs under primitiva förhållanden i så måtto som den inte är en individuell utan en kollektiv verksamhet. Den är därmed nära besläktad med uppvaktningens och äktenskapets organisering, där det ofta gäller att med mer eller mindre fredliga medel skaffa sig en hustru från annan ort. Handeln har alltså sin tyngdpunkt i mötet mellan olika samhällen, och 
en av dess uppgifter är att åstadkomma utbyte av varor. Sådana möten skapar inte, som prisbildande marknader gör, utbytespriser utan förutsätter i stället sådana. Det är inte fråga om vare sig enskilda handelsmäns person eller enskilda vinstmotiv. Oavsett om en hövding eller en kung handlar för samhällets räkning efter att ha samlat in "exportvarorna" från dess medlemmar eller om gruppen själv möter sina motparter på stranden för att byta, så är förfarandet väsentligen kollektivt. Utbyte mellan handelspartner förekommer ofta men det gör naturligtvis också partnerförhållanden vid uppvaktning och giftermål. Enskilda och kollektiva handlingar är sammanflätade med varandra.

Genom betoningen på "anskaffning av varor från annan ort" som konstitutivt element för handeln framhävs den dominerande roll som importintresset spelade under handelns tidiga historia. Under I80otalet fick däremot exportintressena en allt överskuggande betydelse - ett typiskt utbytesfenomen.

Eftersom något måste transporteras över stora avstånd och dessutom i två motsatta riktningar består handeln enligt sakens natur av flera komponenter, exempelvis personal, varor, transporter och tvåsidighet, som alla kan brytas ner enligt sociologiskt eller tekniskt betydelsefulla kriterier. Genom att närmare granska dessa fyra faktorer hoppas jag kunna lära mig något om handelns skiftande plats i samhället.

För det första har vi de personer som är engagerade i handeln. "Anskaffning av varor från annan ort" kan ske antingen utifrån motiv som står i förbindelse med köpmannens ställning i samhället och omfattar då som regel element av plikt eller samhällsservice (statusmotiv), eller på grund av den materiella vinst som tillfaller honom personligen genom inköps- och försäljningstransaktionen (vinstmotivet).

Trots många möjliga kombinationer av dessa drivkrafter framstår å ena sidan hedern och plikten och å andra sidan vinsten som de främsta motiveringarna. Om "statusmotivet", som ofta är fallet, förstärks av materiella förmåner tar de senare som regel inte form av en vinst åstadkommen genom utbyte utan som rikedomar eller jordförläningar skänkta av kungen, templet eller länsherren åt köpmannen som ersättning. De vinster som utbytet skapar är naturligtvis högst obetydliga jämfört med vad länsherren tilldelar den fyndige och framgångsrikt speku- 
lerande köpmannen. Således blir den som driver handel av plikt- eller hedersskäl rik, medan den som driver handel för snöd vinnings skull förblir fattig, vilket är ytterligare ett skäl till att vinstmotivet står i skuggan i det arkaiska samhället.

Man kan också närma sig personfrågan utifrån den levnadsstandard som ett samhälle tycker är lämplig för den som driver handel.

Det arkaiska samhället i allmänhet känner som regel inte till någon annan position för köpmannen än högst upp eller längst ner på samhällsstegen. Den första positionen är förbunden med det styre som handelns politiska och militära villkor förutsätter, den andra är beroende av det enkla arbetet med att transportera varor. Detta faktum är av stor betydelse för förståelsen av handelns organisation under forna tider. En köpman kan inte tillhöra medelklassen, åtminstone inte om han ska räknas in bland samhällets medborgare. Förutom Fjärran Östern, som jag här måste bortse från, finns det från förmodern tid bara dokumenterade tre betydelsefulla exempel på en bred kommersiell medelklass: den hellenistiske köpmannen av huvudsakligen främmande ursprung som verkade i stadsstaterna i Medelhavets östra del, den överallt förekommande islamiske köpmannen som överförde hellenistiska sjöfartstraditioner till basaren och slutligen ättlingarna till Pirennes "flytande skum" i Västeuropa, en sorts kontinentala bofasta främlingar från medeltidens andra tredjedel. Den klassiska grekiska medelklass som prisades av Aristoteles var inte en kommersiell utan en jordägande klass.

Ett tredje angreppssätt är mer historiskt. Under antiken fanns det tre typer av köpmän: handelsagenten, den bofaste främlingen (metoikern) och "utlänningen".

Handelsagenten dominerade den mesopotamiska scenen från den sumeriska begynnelsen till islams genombrott, det vill säga under cirka tre tusen år. Egypten, Kina, Indien, Palestina, det förcolumbianska Mellanamerika och det ursprungliga Västafrika kände inte till någon annan typ av köpman. Den bofasta främlingen framträdde först i Aten och några andra grekiska städer som köpman och hänfördes till de lägre samhällsklasserna. Han blev med hellenismen prototypen för en grekisktalande eller levantinsk kommersiell medelklass från Indusdalen till Herakles stoder. Utlänningen finns förstås överallt. Han driver handel 
med utländska besättningar och fartyg; han varken "tillhör" samhället eller åtnjuter den bofaste främlingens begränsade status utan är medlem av ett helt annat samhälle.

En färde distinktion är antropologisk. Den ger nyckeln till denna egendomliga gestalt, den handelsidkande utlänningen. Trots att de "handelsfolk" som dessa utlänningar tillhörde var jämförelsevis få svarade de för den allmänt spridda institutionen "passiv handel". Handelsfolken skilde sig inbördes åt i ett viktigt hänseende: handelsfolk i egentlig mening var för sin försörjning uteslutande beroende av handeln som hela befolkningen var direkt eller indirekt engagerad i, exempelvis fenicierna, rhodensarna, invånarna i Gades (det moderna Cádiz) eller under vissa perioder armenierna och judarna; hos andra folk - som utgjorde en större grupp - var handeln bara en av många sysslor som emellanåt engagerade en betydande del av befolkningen under kortare eller längre perioder (ibland reste hela familjer). Exempel på detta är haussa- och mandingofolken i västra Sudan. Mandingo går också under namnet duala, men bara, som det nyligen visade sig, då de bedriver handel utomlands. Tidigare uppfattades de som två skilda folkslag av dem som de besökte under sina handelsexpeditioner.

För det andra måste handelns organisation under äldre tider få olika form beroende på vilka varor som transporteras, vilket avstånd som tillryggaläggs, vilka hinder som övervinns av transportmedlen och vilka politiska och miljömässiga villkor som föreligger för handelsföretaget. Av denna om inte av någon annan anledning är all handel ursprungligen specifik. Varorna och transporten av dem gör den specifik. Det kan inte finnas något sådant som handel "i allmänhet".

Fäster man inte full vikt vid detta faktum blir det omöjligt att förstå handelsinstitutionernas tidiga utveckling. Beslutet att införskaffa vissa typer av varor från en bestämd, avlägsen ursprungsplats kommer att fattas under omständigheter som skiljer sig från dem under vilka andra slags varor måste införskaffas någon annanstans ifrån. Handelsföretag är av denna anledning en diskontinuerlig angelägenhet. De begränsas till konkreta åtaganden som utförs ett i sänder utan att skapa någon kontinuerlig sysselsättning. Det romerska societas var i likhet med det senare commenda en handelsförbindelse som ingicks för ett enda åta- 
gande. Endast societas publicanorum, som verkade som skatteförpaktare och entreprenörer, hade korporativ karaktär. Permanenta köpmannaföreningar uppstår inte förrän under modern tid.

Handelns specificitet förstärks i normala fall genom nödvändigheten att anskaffa importerade varor med hjälp av exporterade. Råder inte marknadsvillkor tenderar importen och exporten nämligen att falla under olika system. Den process genom vilken varorna samlas in för export skiljer sig vanligen från, och är relativt oberoende av, den process genom vilken de importerade varorna omfördelas. Den förra kan vara en fråga om avgifter, skatter, feodala gåvor eller någon annan beteckning för de varor som strömmar till centrum, medan den omfördelade importen kan strömma genom helt andra kanaler. Hammurabis seisachteia tycks ha gjort ett undantag för $s i$-mu-varor, som ibland kan ha varit importvaror som vidarebefordrats från kungen via handelsagenter till arrendatorer som ville byta till sig dem mot sina egna produkter. I aztekernas fjärrhandel verkar det ha funnits liknande inslag.

Vad naturen gjort olika gör marknaden lika. Till och med skillnaden mellan varor och transporter kan utplånas eftersom båda kan köpas och säljas på marknaden, den ena på varumarknaden och den andra på fraktoch försäkringsmarknaden. I båda fallen är det fråga om tillgång och efterfrågan och priser bildas på samma sätt. Transporter och varor, dessa handelns grundläggande beståndsdelar, får en gemensam nämnare i form av kostnader. Ett intresse för marknaden och dess konstlade homogenitet leder alltså till en riktig ekonomisk teori snarare än till en riktig ekonomisk historia. Vi kommer till slut att finna att handelsvägarna och transportmedlen inte behöver vara av mindre genomträngande betydelse för handelns institutionella former än de typer av varor som transporteras. I alla dessa fall inverkar nämligen de geografiska och tekniska förhållandena och samhällsstrukturen på varandra.

På tvåsidighetens rationella grund står vi inför tre huvudtyper av handel: gåvohandel, styrd handel och marknadshandel. Gåvohandeln förenar parterna i ömsesidiga relationer, till exempel gästande vänner, kulaparter och besökande sällskap. Under årtusendenas lopp bedrevs handeln mellan imperierna som gåvohandel - ingen annan grund skulle ha uppfyllt situationens villkor lika väl. Handeln organiseras här vanligen på ett 
ceremoniellt sätt och omfattar ömsesidiga presentationer, diplomatiska uppdrag, politiska förbindelser mellan hövdingar eller kungar. Varorna är rikedomar som cirkulerar inom eliten; i gränsfallet med besökande sällskap kan de vara av mer "demokratisk" karaktär. Men kontakterna är obetydliga och utbyte förekommer sällan.

Den styrda handeln har sin fasta grund i överenskommelser som är mer eller mindre formella. Eftersom det i regel är importintresset som är bestämmande går handeln genom statligt kontrollerade kanaler. Exporthandeln organiseras vanligen på liknande sätt. Följaktligen bedrivs handeln som helhet med administrativa metoder. Detta gäller de former under vilka affärerna görs, inklusive arrangemang rörande "priser" och proportioner hos de enheter som utbyts, hamnresurser, vägning, kvalitetskontroll, det fysiska utbytet av varor, lagring, förvaring, kontroll av handelspersonal, reglering av "betalningar", krediter, prisskillnader. Något av detta är naturligtvis kopplat till insamlingen av exportvaror och fördelningen av importvaror, som bådadera tillhör den inhemska ekonomins omfördelande sfär. De varor som importeras ömsesidigt är standardiserade i fråga om kvalitet och förpackning, vikt och andra lätt fastställbara kriterier. Det är bara med sådana "handelsvaror" som handel bedrivs. Ekvivalensen fastställs i enkla relationer mellan enheter; i princip drivs handeln i förhållandet ett till ett.

I detta förfarande ingår ingen köpslagan; ekvivalenserna är fastställda en gång för alla. Men eftersom det inte går att undvika anpassning till förändrade omständigheter köpslår man om andra moment än priset, till exempel måttet, kvaliteten eller betalningsmedlet. Det går att argumentera i det oändliga om livsmedels kvalitet, egenskapen och vikten hos de enheter som används, proportionerna mellan valutor om fler än en valuta används. Man till och med köpslår om "vinsten”. Det grundläggande är här naturligtvis att hålla priserna oförändrade; om de i ett nödläge måste anpassas till den faktiska utbudssituationen uttrycks detta som att man handlar med varandra i förhållandet två till ett eller två och en halv till ett eller, som vi skulle säga, med Ioo eller I50 procents vinst. Denna metod att köpslå om vinsten till stabila priser, som kan ha varit ganska allmän i det arkaiska samhället, är väl bestyrkt från centrala Sudan så sent som på I80o-talet. 
Styrd handel förutsätter relativt permanenta handelsorgan, såsom stater eller åtminstone statligt auktoriserade företag. Det kan räcka med en tyst överenskommelse med urinvånarna som vid traditionella eller hävdvunna förhållanden, men handel mellan suveräna organ kräver formella fördrag, till och med så relativt tidigt som under andra årtusendet f.Kr.

När styrda former av handel - under gudarnas höga beskydd - väl har införts i ett område kan de utövas utan tidigare ingångna överenskommelser. Den viktigaste institutionen är, som vi nu börjar inse, handelshamnen, den plats där all styrd utrikeshandel sker. Handelshamnen erbjuder militär trygghet åt den egna statsmakten och skydd för den främmande köpmannen, ankrings-, lossnings- och lagringsmöjligheter, förmånen av rättslig reglering, enighet om vilka varor som omfattas av handeln och vilka "proportioner" som gäller mellan de olika handelsvarorna i de blandade förpackningarna eller "sorteringarna".

Marknadshandel är den tredje typiska formen av handel. Här är det utbytets integrationsform som förbinder parterna med varandra. Denna jämförelsevis moderna variant av handel släppte lös en ström av materiell rikedom över Västeuropa och Nordamerika. Även om den just nu befinner sig i nedgång är den fortfarande den viktigaste handelsformen. Det finns oändligt många varor att bedriva handel med, och marknadshandeln organiseras enligt tillgångs-, efterfråge- och prismekaniken. Marknadsmekanismen kan tillämpas på de flesta områden, inte bara på varor utan också på varje särskilt element i handeln - lagring, transport, risk, kredit, betalning etc. - genom bildandet av speciella marknader för frakt, försäkring, kortfristiga krediter, kapital, lagerutrymme, olika banktjänster och så vidare.

Ekonomhistorikerns intresse inriktas i dag huvudsakligen på frågorna: När och hur kopplades handeln till marknader? Vid vilken tidpunkt och på vilken plats möter vi det allmänna resultat som är känt som marknadshandel?

Strängt taget omintetgörs sådana frågor av den utbyteslogik som tenderar att oskiljaktigt smälta samman handel och marknad. 


\section{Penningbruk}

I utbytesprocessen fungerar pengar som ett indirekt bytesmedel. Moderna pengar används för betalning och som "måttstock" just därför att de utgör ett bytesmedel. Våra pengar är följaktligen "universalpengar”. Andra bruk är bara betydelselösa varianter av utbytesbruket, och alla former av penningbruk är beroende av marknadernas existens.

Den substantivistiska definitionen av pengar är i likhet med den substantivistiska definitionen av handel oberoende av marknaderna. Den härleds ur de bestämda bruk som man kan göra av kvantifierbara föremål. Dessa bruk är betalning, måttstock och utbyte. Pengar definieras därför här som kvantifierbara föremål som förekommer i ett eller flera av dessa bruk. Frågan är huruvida det går att skapa självständiga definitioner av dessa bruk.

Definitionerna av de olika penningbruken innehåller två kriterier: den sociologiskt definierade situation i vilken bruket uppstår och den operation som utförs med penningföremålen i denna situation.

Betalning är fullgörelsen av en förpliktelse där kvantifierbara föremål byter ägare. Det är inte bara fråga om en förpliktelse utan om flera, eftersom det är först när ett föremål används för att fullgöra mer än en förpliktelse som vi kan tala om det som ett "betalningsmedel" i termens karakteristiska mening (annars fullgörs bara en förpliktelse som ska fullgöras in natura).

Betalningsbruket tillhör de vanligaste penningbruken i forna tider. Förpliktelserna har vanligen inte sitt ursprung i några affärstransaktioner. I primitiva samhällen görs betalningar regelbundet i samband med institutioner som brudpris, blodspenningar och böter. Sådana betalningar fortsätter i det arkaiska samhället men överskuggas där av vanliga tullar, skatter, arrenden och tributer som ger upphov till betalningar i stor skala.

När pengar används som måttstock eller för bokföring är det fråga om att jämställa mängder av olika slags varor för bestämda ändamål. "Situationen" är antingen byteshandel eller lagring och hantering av stapelvaror; "operationen" består i att ge de olika föremålen numeriska mått så att man lättare kan handskas med dem. I byteshandelns fall kan således summeringarna av föremål på ömse sidor till slut jämställas, och när 
det gäller hanteringen av stapelvaror ges möjlighet till planering, saldering, budgetering och allmän bokföring.

Att kunna använda pengar som måttstock betyder mycket för elasticiteten i ett omfördelande system. Det är viktigt att kunna jämställa varor som korn, olja och ull, i vilka skatter eller arrenden måste betalas eller alternativt ransoner eller löner kan krävas, eftersom det garanterar både utbetalare och betalningsmottagare en möjlighet att välja mellan olika stapelvaror. På samma gång skapas förutsättningar för storskalig finansiering in natura, vilket kräver begrepp som tillgång och balans eller med andra ord utbytbarhet mellan stapelvaror.

Utbytesbruket av pengar uppstår ur ett behov av kvantifierbara föremål för indirekt utbyte. "Operationen” består i att förvärva enheter av sådana föremål genom direkt utbyte i syfte att förvärva de önskade föremålen genom ytterligare en byteshandling. Ibland är penningföremålen tillgängliga från början och det tvåfaldiga utbytet bara avsett att öka mängden av samma föremål. En sådan användning av kvantifierbara föremål utvecklas inte ur slumpartade byteshandlingar, vilket var en föreställning som fick stöd av I70o-talets rationalism, utan i samband med organiserad handel, särskilt på marknader. I frånvaron av marknader är pengarnas utbytesbruk inte mer än ett underordnat kulturinslag. Att stora handelsfolk som kartager och fenicier visade en sådan motvilja mot användningen av mynt, denna nya penningform som var så väl lämpad för utbyte, kan ha berott på att handelsimperiernas hamnar inte var organiserade som marknader utan just som "handelshamnar".

Man bör lägga märke till två utvidgningar av pengarnas innebörd. Den ena utsträcker penningdefinitionen inte bara till fysiska föremål utan även till ideala enheter; den andra omfattar förutom de tre konventionella penningbruken också bruket av penningföremål som operationella uppfinningar.

Ideala enheter är bara verbaliseringar eller skrivna symboler som används som om de vore kvantifierbara enheter och främst för betalning eller som måttstock. "Operationen" består i att manipulera med skuldkonton enligt vissa spelregler. Sådana konton är vanliga i primitiva samhällen och är inte, som man ofta trodde, utmärkande för monetariserade ekonomier. De äldsta tempelekonomierna i Mesopotamien och 
de tidiga assyriska köpmännen praktiserade konsten att balansera konton utan hjälp av penningföremål.

$\AA$ andra sidan kan det vara klokt att nämna de operationella konstgrepp som kan göras med pengar, hur ovanliga de än må vara. Ibland användes i det arkaiska samhället kvantifierbara föremål i aritmetiska, statistiska, skattemässiga, administrativa eller andra icke-monetära syften som hade med det ekonomiska livet att göra. Under I700-talet använde man sig i västafrikanska Ouidah av kaurisnäckan som pengar för statistiska ändamål, och dambabönor (som aldrig användes som pengar) tjänade som guldvikt och utnyttjades i den egenskapen som hjälpmedel vid bokföringen.

De äldsta pengarna tjänar, som vi sett, speciella syften. Olika slags föremål används i de olika penningbruken; dessutom införs de olika bruken oberoende av varandra. Konsekvenserna är av det mest långtgående slag. Det ligger exempelvis ingen motsägelse i att "betala" med något som man inte kan köpa något för, inte heller i att som "måttstock" använda föremål som inte brukas som bytesmedel. I Hammurabis Babylonien var korn betalningsmedel; silver var den allmänna måttstocken; för utbyte, som sällan förekom, användes bådadera jämte olja, ull och vissa andra stapelvaror. Det står klart varför penningbruket i likhet med handelsverksamheten kan nå en nästan obegränsad utvecklingsnivå, inte bara utanför de marknadsdominerade ekonomierna utan i själva frånvaron av marknader.

\section{Marknadselement}

$\mathrm{Nu}$ kommer vi till själva marknaden. Marknaden är platsen för utbytet; marknaden och utbytet har samma utsträckning. Enligt våra förutsättningar kan det ekonomiska utbytet reduceras till byteshandlingar som utförs genom köpslagan, och det förkroppsligas i marknader. Utbytet beskrivs alltså som det viktigaste ekonomiska förhållandet och marknaden som den viktigaste ekonomiska institutionen. Marknadens definition härleds logiskt ur utbytets premisser.

Marknaden och utbytet har som substantivistiska termer självständiga empiriska egenskaper. Vad är innebörden av utbyte och marknad i detta sammanhang? Och i vilken utsträckning är de nödvändigtvis förbundna med varandra? 
Utbyte är substantivistiskt definierat en ömsesidig tillägnelserörelse där varor byter ägare. En sådan rörelse kan, som vi redan sett, ske till fastställda eller till framförhandlade priser. Endast de senare är resultatet av köpslagan mellan parterna.

Närhelst utbyte förekommer bildas ett pris. Detta gäller antingen priset är fastställt eller bildas efter förhandlingar. Man ska lägga märke till att utbyte till framförhandlade priser är identiskt med "utbyte som integrationsform”. Endast detta utbyte är typiskt begränsat till en bestämd typ av marknadsinstitution, nämligen den prisbildande marknaden.

Marknadsinstitution kommer här att definieras som en institution bestående av en mängd människor som utbjuder något, en mängd människor som efterfrågar något, eller både och; det rör sig om en mängd människor som är angelägna om att göra sig av med eller förvärva varor i ett utbyte. Även om marknadsinstitutioner därför är bytesinstitutioner är marknad och utbyte inga sammanfallande begrepp. Utbyte till fastställda priser sker under ömsesidiga eller omfördelande integrationsformer; utbyte till framförhandlade priser är, som sagt, begränsat till prisbildande marknader. Det kan tyckas paradoxalt att utbyte till fastställda priser skulle vara förenligt med alla integrationsformer utom med utbytets. Likväl följer detta logiskt eftersom endast förhandlingsutbytet representerar utbyte som integrationsform.

Det bästa sättet att närma sig marknadsinstitutionernas värld tycks vara genom "marknadselementen”. Därigenom får vi till slut inte bara en vägledning genom alla de olika former som inordnas under beteckningen marknad eller institution av marknadskaraktär utan också ett redskap med vilket vi ingående kan analysera några av de konventionella begrepp som hindrar vår förståelse av dessa institutioner.

Två marknadselement bör betraktas som specifika, nämligen människor som utbjuder och människor som efterfrågar; om endera existerar talar man om marknadsinstitution (om båda existerar kallas det marknad och om bara det ena existerar institution av marknadstyp). Därnäst i betydelse kommer ekvivalensen, det vill säga det pris till vilket utbytet sker; alltefter ekvivalensens karaktär är det fråga om marknader med fastställda priser eller prisbildande marknader.

Konkurrens är ytterligare något som karakteriserar vissa marknadsinstitutioner, såsom prisbildande marknader och auktioner, men till 
skillnad från ekvivalenserna är den ekonomiska konkurrensen begränsad till marknaderna. Slutligen finns det element som kan betecknas som funktionella. De förekommer vanligen utanför marknadsinstitutionerna men kan tillsammans med människorna som utbjuder och människorna som efterfrågar forma dessa institutioner på ett sätt som kan vara av stor praktisk betydelse. Bland dessa funktionella element ingår den fysiska platsen, de existerande varorna, lag och sedvänja.

Denna mångfald av marknadsinstitutioner har på senare tid fördunklats av den formella föreställningen om en tillgångs-, efterfråge- och prismekanik. Det är inte att undra på att det är i förhållande till de centrala begreppen tillgång, efterfrågan och pris som ett substantivistiskt angreppssätt leder till ett väsentligt vidgat perspektiv.

Jag betraktade ovan människor som utbjuder och människor som efterfrågar som särskilda marknadselement. Beträffande den moderna marknaden skulle detta naturligtvis inte gå för sig; där finns det en prisnivå vid vilken baisse blir hausse och en annan vid vilken miraklet görs ogjort. Detta har fått många att förbise det faktum att köpare och säljare är åtskilda på alla andra marknader än den moderna typen av marknad. Detta ger i sin tur stöd åt en tvåfaldig missuppfattning. För det första framstod "tillgång och efterfrågan" som förenade elementära krafter medan de i själva verket bestod av två mycket olika komponenter, nämligen å ena sidan en mängd varor och å andra sidan ett antal människor som står i förbindelse med varandra som köpare och säljare av dessa varor. För det andra tycktes "tillgång och efterfrågan" vara lika oskiljaktiga som siamesiska tvillingar trots att de faktiskt bildade olika grupper av personer beroende på om de förfogade över varorna som sina resurser eller eftersträvade dem enligt sina behov.

De som utbjuder och de som efterfrågar behöver därför inte vara närvarande tillsammans. När exempelvis den segrande generalen auktionerar ut krigsbytet till högstbjudande förekommer det bara människor som efterfrågar; på liknande sätt finns det bara människor som utbjuder när kontrakt överlåts till den som bjuder lägst. Ändå var både auktioner och anbudsgivningar allmänt förekommande i det arkaiska samhället, och i det antika Grekland räknades auktionerna som en av föregångarna till den egentliga marknaden. Det var åtskillnaden mellan människor som 
utbjuder och människor som efterfrågar som skapade organisationen för alla förmoderna marknadsinstitutioner.

Vad gäller det marknadselement som vanligen kallas "pris" inordnas det här under ekvivalenskategorin. Genom att använda denna generella term bör man kunna undvika missförstånd. Pris antyder fluktuation medan ekvivalens saknar denna association. Själva uttrycket "fast" eller "bestämt" pris antyder att priset kunde ändras innan det fastställdes eller bestämdes. Språket självt gör det alltså svårt att uttrycka sakernas rätta tillstånd, nämligen att "priset" ursprungligen är en strängt fastställd kvantitet i vars frånvaro ingen handel kan påbörjas. Priser som förändras eller fluktuerar av konkurrensskäl är en jämförelsevis sen utveckling, och framväxten av dem är av största intresse för antikens ekonomiska historia. Traditionellt förutsatte man motsatt ordningsföljd: priset betraktades som resultatet av handel och utbyte, inte som deras förutsättning.

"Pris" är beteckningen på kvantitativa kvoter mellan varor av olika slag och bildas genom byteshandel eller köpslagan. Det är denna form av ekvivalens som är karakteristisk för ekonomier som integreras genom utbyte. Men ekvivalenserna begränsas inte till bytesrelationer. Även under en omfördelande integrationsform är ekvivalenser vanliga. De betecknar det kvantitativa förhållandet mellan de olika varor som kan accepteras som betalning för skatter, arrenden, tullar, böter eller som anger kvalifikationer för ett medborgarskap som beror av förmögenhetsstorlek. Ekvivalensen kan också fastställa den kvot efter vilken löner eller ransoner in natura kan krävas, alltefter mottagarens önskemål. Elasticiteten i ett stapelsystem - planering, saldering, bokföring - vilar på denna uppfinning. Ekvivalensen betecknar inte här vad som bör ges för en annan vara utan vad som kan krävas $i$ stället för den. Under ömsesidiga integrationsformer bestämmer ekvivalenserna den mängd som är "adekvat" i förhållande till den symmetriskt placerade parten. Detta beteendesammanhang skiljer sig klart från både utbytet och omfördelningen.

Prissystemen kan under sin utveckling över tiden innehålla skikt av ekvivalenser som uppstått under olika former av integration. De hellenistiska marknadspriserna visar rika spår av att ha härletts ur de omfördelande ekvivalenserna från de äldre kilskriftskulturerna. De trettio silverpenningar som Judas mottog som belöning för att ha förrått Jesus var 
en nära variant av den ekvivalens som förekom i Hammurabis lagsamling ungefär I 700 år tidigare. Å andra sidan återspeglade Sovjetunionens omfördelande ekvivalenser under lång tid I80o-talets världsmarknadspriser. Även dessa hade sina föregångare. Max Weber konstaterade att den västerländska kapitalismen i frånvaron av riktiga kalkyleringsgrunder skulle ha varit omöjlig om det inte hade varit för det medeltida nätverket av föreskrivna och reglerade priser, hävdvunna avgifter etc., det vill säga arvet efter skråets och godsets institutioner. Prissystemen kan alltså ha en egen institutionell historia uttryckt i äldre typer av ekvivalenser.

Det är med hjälp av begrepp som handel, pengar och marknad som så grundläggande ekonomisk- och socialhistoriska problem som ursprunget till fluktuerande priser och marknadshandelns utveckling bäst kan angripas och, hoppas jag, slutligt lösas.

Sammanfattningsvis: En kritisk granskning av de definitioner av handel, pengar och marknad som är förenade med utbytesprocessen bör ge oss begrepp som kan bilda grund för samhällsvetenskaperna i deras ekonomiska aspekt. Den teoretiska, politiska och ideologiska betydelsen av detta erkännande bör ses i ljuset av den gradvisa institutionella omvandling som har pågått sedan första världskriget. Till och med i förhållande till marknadssystemet självt är det en aning förlegat att ha marknaden som enda referensram. Det bör nu stå klarare än vad det ibland har gjort i det förflutna, att marknaden kan ersättas som allmän referensram först om samhällsvetenskaperna lyckas utveckla en vidare referensram till vilken marknaden själv är hänförbar. Detta är faktiskt i dag vår viktigaste intellektuella uppgift på de ekonomiska studiernas område. Som jag har försökt visa måste en sådan begreppsstruktur grundas på den substantivistiska innebörden av "det ekonomiska". 


\section{Moderna klassiker}

\section{Karl Polanyi \\ Den stora omdaningen}

\section{Arkiv förlag}

Den stora omdaningen (The Great Transformation från 1944) är den klassiska skildringen av det liberala marknadssamhällets uppgång och fall från slutet av I70o-talet till det andra världskriget. Polanyi kritiserar tanken att de frikopplade marknaderna är ett naturligt socialt tillstånd. De är för honom varken eviga eller spontant framvuxna lösningar. Iscensättandet av den liberala utopin - att marknaderna automatiskt kan reglera samhällens och människors väl och ve - krävde tvärtom politiska ingrepp och lagändringar av gigantisk omfattning.

Tredje ombrutna och översedda upplagan 20I2, 344 sidor

»Läs mer om boken på www.arkiv.nu« 


\section{Fronesis}

\section{Prenumerera på Fronesis}

I tidskriften Fronesis finner du vår tids främsta samhällsteoretiker i svensk och internationell debatt. Fronesis erbjuder både introduktion och fördjupning i välkomponerade temanummer.

Läs om alla våra nummer på www.fronesis.nu

I nr 54-55, Ekonomiskt vetande, undersöker vi nationalekonomins kris och förutsättningarna för ett alternativt ekonomiskt vetande i kölvattnet efter den globala finanskrisen 2008.

Gilla Fronsesis sida på Facebook för uppdateringar om nya nummer, seminarier och annat som händer. Köp lösnummer eller teckna prenumeration på www.fronesis.nu 